\title{
Pattern of Women's Education in Minangkabauthrough the Lingual Forms in the Myth of Palasik
}

\author{
R Febrina ${ }^{1}$, D N Syafar ${ }^{2}$ \\ \{ ${ }^{1}$ riafebrina03@gmail.com, ${ }^{2}$ dianoviany.s@gmail.com \} \\ ${ }^{1}$ Universitas Andalas Padang, Indonesia \\ ${ }^{2}$ STKIP PGRI Sumatera Barat Padang, Indonesia
}

\begin{abstract}
The purposes of the research are (1) to describe the lingual forms used by Minangkabau people in developing in the myth of palasik; (2) to explain the functions and meanings of lingual forms in the myths of palasik used by the Minangkabau people; and (3) to explain the pattern of women's education in Minangkabau through lingual forms in the palasik myth. The method of the research is the descriptive research method proposed by Taylor, Bogdan, and DeVault (2015) to produce descriptive data in the form of lingual forms used by Minangkabau people in palasik myths, and Cresweel (2018) to explain the pattern of women's education in social tradition aspects of the Minangkabau people, especially through the palasik myth. The results of the research found that (1) the palasik myths developes in Minangnese society through lingual forms, such as the prohibition of pregnant women and nursing mothers to go outside the home; prohibition of drying baby clothes outside the home; the prohibition of avoiding people who follow Palasik black magic; obligation for pregnant women, nursing mothers, and babies to use amulets, attach garlic to clothes, and use white iron in their hands; and the obligation to wear an undershirt or reversed shirt to the baby; (2) the functions and meanings of lingual forms in palasik myths are spiritual functions to control social life and psychological functions to control individual life; and (3) the Minangnese have an educational pattern for women, especially for pregnant women and nursing mothers in taking care of themselves and babies.
\end{abstract}

Keywords: Minangkabau, myths, palasik, traditional education, women

\section{INTRODUCTION}

Minangnese use the matrilineal system of kinship, meaning women have greater power in both family and society. Minangnese also believe in myth as a part of life and also becomesa media to control thesociety lives.Myths are defined as tales believed as true, usually sacred, set in the distant past or other worlds or parts of the world, and with extra-human, inhuman, or heroic characters[1]. There are some myths that appear in Minangnese society related with women [2].Myth is believed by the Minangnese to control life in terms of mystical or supranatural, that is palasik in which Minangnese believe in palasik to control the women's llives, especially for pregnant women and nursing mothers.In Minangkabau, pregnant women and nursing mothers must obey a number of things to avoid palasik. If pregnant women and 
nursing mothers do not do this, it will have an impact on their pregnancy or baby, such as miscarriage, wine pregnancy, or the baby-dying. Therefore, it is important for pregnant women and nursing mothers to obey everything that is prohibited through the palasik myth.

Regarding the palasik myth that developes in Minangkabau, it turns out that it has similarities with a number of myths in other countries, namely kuyang (Dayak), leak (Bali), empusa (Greece), chupacabra (Latin America), dracula (Romania)[3], and vampires (Balkans) ), namely creatures that can suck human blood[4].

In Minangkabau,palasik[5] is believed to be a creature that is able to suck the fetus that a pregnant woman contains, suck blood through the crown of a baby, and suck mother's milk so the baby does not want to breastfeed. Meanwhile, in Balinese mythology, palasik is called leak, the evil witch. "Le" means witch and "ak" means evil. Leak was seen at night by the poacher hunter leak. In the afternoon, leak looks like a human. At night, the leak explored the cemetery to find organs from the human body that were used to make magic potions. Magic potion can change the form of leak into tigers, monkeys, and pigs. As stated by Atmadja, et.al [6], in Balinese society,leak can be a human head with organs hanging from it or a flying leak to look for a pregnant woman and suck their blood when her baby is still in the womb. In fact, the community believes there are three known leaks. Two of them are women and one is a man. According to Balinese beliefs, a leak with a human head practices black magic and requires fetal blood to live.

In Thailand, palasik is known as Krasue, which is a ghost called manananggal which preys on pregnant women with elongated proboscis-like tongues. Manananggal is the spirit of a beautiful old woman who is able to cut her upper body to fly at night with large bat wings to prey on victims of pregnant women in their homes. Meanwhile, McClelland in[7]states that in the popular culture of Western Europe and North America today, palasik is known as vampire and dracula. Almond [8], Harney [9] describes four of the most common types of vampires. Among them is someone who has a violent life who chooses to become a vampire; children born out of wedlock; someone who suffers from violence, such as murder; and ritual funeral practices that made the corpse a vampire.

Palasik(palasic) is a blood sucking ghost. The palasik appearance alike a floating head. However, some Minangkabau people tend to believe that palasik sightings are ordinary human beings who areseeking black magic[10]. As a result, people find it difficult to recognize people around who adhere to black magic. As such, they obey a number of restrictions that are conveyed to avoidpalasik. The prohibition on avoiding palasik is disseminated by the public through oral. Parents or relatives will convey certain linguals to control the lives of pregnant women and nursing mothers that can be seen in the following datum 1.

\author{
Datum1 \\ Ibu : Lah bapakai dasun tadi, Ti? \\ Sudah dipakai dasun tadi, Ti? \\ 'Apakah sudah disematkan bawang putih dalam baju, Ti?' \\ ( Have you pinned the garlic, Ti?) \\ Yati : Alah, Ma. \\ Sudah, Ma. \\ 'Sudah, Ma.' \\ (Yes, Mom.)
}


Yati is a 36-year-old woman who is pregnant six months old. At that age, a pregnant woman must attach dasun or garlic to the clothes worn. Dasun or garlic is considered able to counteract the effects of circulating palasik.

Although technology has developed at this time and people live in urban areas, believing in palasik is still a tradition. The use of dasun or garlic as a way to ward off palasik is an obligation carried out by pregnant women in Minangkabau. However, the belief of the Minangkabau people towards palasik today can be analyzed logically. The palasik myth is used by the Minangkabau people to regulate the lives of women in Minangkabau, especially pregnant women and nursing mothers. A number of utterances delivered from parents to girls who are pregnant or who are breastfeeding are non-formal education developed in their lives. Based on this, research on "The Pattern of Education for Women in Minangkabau through Lingual Forms in the Palasik Myth" is important.

This study explains the pattern used by Minangkabau people in providing education to women, especially to pregnant women and nursing mothers. The educational pattern in question is related to the pattern of non-formal education that develops verbally in each household. In general, oral speech produced by the Minangkabau community became the data in this study. However, specifically, utterances containing the palasik myth used by the Minangkabau people in Padang City became the data in this study.

To analyze the forms, functions, and lingual meanings used by the Minangkabau people, linguistic anthropology studies are used. In linguistic anthropology, a sign that can communicate referential messages and relational messages is used in social and cultural contexts. There are four aspects of language use are described to analyze in understanding linguistic signs, namely form, use, ideology, and domain[11]. Therefore, in linguistic anthropology, it is studied social relations of society that move from one event to another, across time and across social spaces, and contribute to local and historical changes in society.

Regarding in this study, a number of linguals used by the people in Minangkabau regarding the palasik myths were analyzed using linguistic anthropology studies. A number of utterances are used by the community to control the lives of their people are explained as events that are interconnected and form a belief system in the community.

\section{RESEARCH METHOD}

This study is a qualitative research method that aims to examine certain cases as a whole. In addition, in the study will be explained in detail certain social problems and will produce relevant data, namely in the form of data expressed in writing and behavior that is real researched and studied as a whole by means of interviews and surveys. The qualitative research method used is descriptive analysis research method proposed by Taylor, et.al[12]to produce descriptive data in the form of lingual forms used by Minangkabau people in the palasik myth, and to explain the pattern of education of women in social traditions Minangkabau people, especially through the palasik myth. In applying the method, various uniqueness of individuals, groups, communities, and / or organizations are expressed in daily life as a whole, detailed, and scientifically accountable.

This is in accordance with the definition of qualitative research also presented by Cresweel[13]that "qualitative research is research that intends to understand the phenomenon of what is experienced by the subject of research, for example behaviors, perceptions, motivations, and actions holistically and by means of descriptions in words words and languages in a specific natural context and by utilizing various natural methods. 
In this study, the focus of the research is the lingual forms, functions, and the meanings of the lingual forms in the palasik myths that developed in Minangkabau society, especially in West Sumatra. This research was conducted in Nagari Padang Laweh, Sungai Tarab District, Tanah Datar District. The location was chosen with the consideration that the community still has tendencies toward the palasik myth.In the implementation of the research method, it is carried out through three stages, namely the data collection stage, the data analysis stage, and the stage of presenting the results of data analysis. At the stage of data collection, it is carried out by interviewtechniques. Interview is a process of submitting questions directly to obtain information for research purposes by way of question and answer while face to face between the questioner or interviewer with the answerer or respondent using a tool called the interview guide.

Data collection using this interview technique is done by using natural setting and in depth interviews. In-depth interviews are conducted to obtain information by way of question and answer while meeting face-to-face between interviewers and informants or interviewees without using interview guides. Interviews are conducted with easy questions, starting with fact information, not on multiple questions, not asking personal questions before the building report, repeating answers for clarification, and giving a positive impression.In addition, observations are also conducted with researchers involved as participating observers (participan observation). Through observation, the behavior and meaning of the behavior are obtained. The use of this technique needs to be done to measure certain aspects and make feedback on these measurements.

At the stage of data analysis, organizing and sorting data into patterns, categories, and basic units is organized so that themes can be found and work hypotheses can be formulated, such as those based on data. According to Miles, et.al[14], data analysis consists of three activities that occur simultaneously, namely data reduction, data presentation, and conclusion / verification. In data reduction, a rough data selection and transformation process is carried out that appears from written records in the field. Meanwhile, the presentation of data is limited to a set of structured information that gives the possibility of drawing conclusions and taking action. Next, conclusions are made after being verified during the study. Verification is conducted after conducting a review of the field notes and after an attempt is made to place a copy of the findings in another set of data. In short, the meanings that emerge from other data must be tested for truth, robustness, and compatibility to become a validity.

\section{RESULT AND DISCUSSION}

Based on research conducted in Nagari Padang Laweh, Sungai Tarab, Tanah Datar, a number of lingual forms are used by the Minangkabau people in developing the Palasik myth. These myths have functions and meanings in people's lives. An explanation of the lingual form, function, and meaning of the palasik myth can be seen as follows.

\subsection{Lingual forms that Spread Out about Palasik myth}

The result of the study are found in the fact that palasik research developed in Minangkabau society through certain lingual forms as follows.

\subsubsection{Prohibition of pregnant women and nursing mothers outside the home}


In Nagari Padang Laweh, pregnant women and nursing mothers are prohibited from going out of the house if there is no urgent need, such as going to the midwife's house, going to the doctor, or to a certain place that requires them outside the home. This can be seen in the following form.

\section{Datum 2}

Etek : Kama juo lai, Sil?

Ke mana juga lagi, Sil?

'Mau pergi ke mana, Sil?'

(Where are you going, Sil?)

Silvia : Ka kadai, Tek.

'Ke kedai, Tek.'

(To shop, Mom!)

Etek : Kau hamil. Suruah lah si Ipaik pai. Beko ndak baisi paruik tuh pulang.

Kamu hamil. Minta saja si Ipaik pergi. Nanti tidak berisi perut tuh pulang.

"Kamu sedang hamil. Suruh Ipaik pergi. Nanti kamu bisa keguguran pas pulang.'

(You are pregnant. You can ask a help to Ipaik. You could lose your baby when arriving at home.)

In this conversation, patternndak baisi paruik is interpreted as a result of palasik actions that will befall Silvia, a 27-year-old pregnant woman.

\subsubsection{Prohibition of drying baby's clothes outside the home}

Datum 3

tu?

Mande : Baok baju ka dalam, Pit, jan dijamua di lua. Ka dihiruik ubun-ubunanak

Bawa baju ke dalam, Sil, jangan dijemur di luar. Mau dihirup ubun-ubun anakmu?

'Jemur baju di dalam rumah, Sil, jangan dijemur di luar. Kamu mau ubunubun anakmu dihisap (palasik)?'

(Dry clothes in the house, Sil, Don't hang out outside. You want a fontanel. Your child is sucked (palasik)

Fitria : Yo, Nde.

$\mathrm{Ya}, \mathrm{Nde}$.

'Ya, Mande.'

(Yes, Mom.)

During the conversation, patterndihiruik ubun-ubun anak tu is interpreted as a result of palasik actions that will afflict one-month-old Fitria baby.

\subsubsection{Prohibit avoiding people who adhere to black magic}

Datum 4

Rika : Mak, itu Mak Itam, takuik awak.

Mak, itu Mak Itam, takut saya.

'Mak, ada Mak Itam, saya takut.'

(Mom, he is Mak Itam, I am fear.)

Mande : Jan lari pulo kau, tamui inyo, minta inyo mancium jo mandoakan anak kau! 
Jangan lari pula kamu, temui dia, minta dia mencium dan mendoakan anakmu!

'Kamu jangan lari, tapi temui dia dan minta dia mencium dan mendokan anakmu!'

(You should not get away, but meet him and ask him to kiss and pray for your son!)

In this conversation, patternminta inyo mancium jo mandoakan anak kau is interpreted as a result of the good that will be accepted by Rika and her child if she meets people who are considered to have knowledge of palasik, then ask for a prayer from him so that she and the child are healthy and avoid palasik.

\subsubsection{Obligations for pregnant women, nursing mothers, and babies using amulets,} pinning garlic on clothes, and using white iron on hands

Datum 5

Mama : Lah bapakai dasun, Na?

Sudah dipakai dasun, $\mathrm{Na}$ ?

'Sudah dipasang bawang putih di baju, Na?'

('Have you pinned the garlic on your dress, $\mathrm{Na?')}$

Tina : Alah, Ma.

Sudah, Ma.

'Sudah, Ma.'

(Yes, Mom.)

Mama : Si Randa lah pakai galang? Baduo-baduo kalian pakai jo dasun.

Awak ka bajalan!

Si Randa sudah pakai gelang? Berdua-dua pakai dengan dasun. Kalian akan berjalan!

'Si Randa sudah mengenakan gelang besi? Kalian berdua harus memakainya (gelang besi dan bawang putih). Kalian akan bepergian!'

(Has Randa wore iron bracelet? You both must wear them (iron bracelet and garlic), because you will go outside!)

Based on above coversation, the patternBaduo-baduo kalian pakai jo dasunis interpreted as a good effect of both being received by Tina and her child if they go out of home while wearing an iron bracelet and garlic. They will be avoided frompalasik.

\subsubsection{Obligation of wearing undershirt or reversed shirt to the baby}

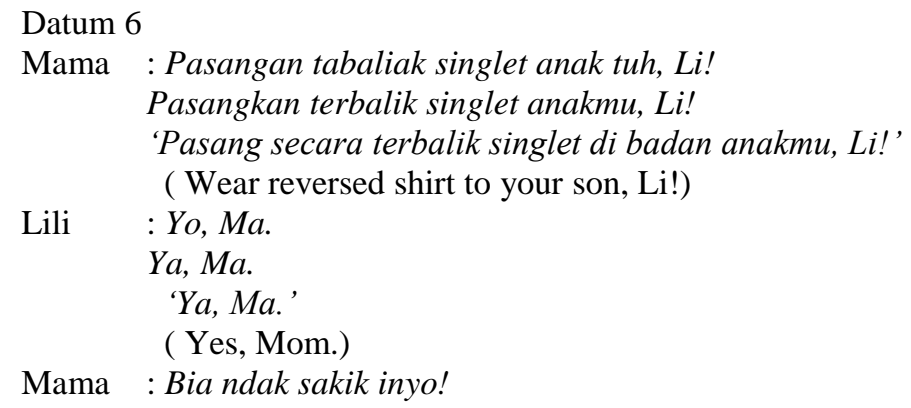


Agar tidak sakit dia!

'Tujuannya agar ia tidak sakit!'

(Hopefully, he is not sick!)

In the conversation, form ofpasangan tabaliak singlet anak tuh, Li! is interpreted as a result of the good that will be received by the child byLili's son if he wears a singlet in reverse, or the outside is on the inside and the inside is on the outside.

\subsection{Function and Meaning of Lingual Forms in the Myth of Palasik Used by the MinangneseSociety}

Various expressions that spread out in Minangnese truth reflect a cultural values, mostly for society in Nagari Padang Laweh, Sungai Tarab, Tanah Datar District. There are six utterances that found in this research. Then,these utterances have certain functions and meanings for the Minangnese community; (1)a spiritual function to control social lifeand (2) psychological function to control individual life.

Spiritual function which can be seen in datum 3 and datum 4. In datum 2, it is explained that the prohibition of drying clothes outside the home is used as a rule of living in Nagari Padang Laweh that a number of baby and nursing mothers clothes are not suitable for drying in the sun. This type of clothing must be placed in certain parts of the house so as not to disturb the views of others. Meanwhile, in datum 4, recommendations to meet people who are considered to have palasik knowledge are intended so that a woman respects anyone and is able to establish good friendship, including those who are considered to have palasik knowledge, such as Mak Itam. The respect given is a social control in community life in Nagari Padang Laweh.

Psychological functions can be seen in datum 1, datum 2, datum 5 , and datum 6 . In datum 1, the palasik myth is used by the Minangnese in Nagari Padang Laweh as a personal control for pregnant women to avoid dangers that do not unexpected. Likewise with datum 2, it is explained that a pregnant woman must avoid unimportant travel so that they avoid danger, such as slippery roads, rocky roads, or obstacles in the form of vehicles in the middle of the road and datum 5 which encourages a mother and child keep away from everything that might happen on a long trip, let alone using a vehicle. In data 6 , it is indicated that these recommendations are intended to protect the baby's child from all possible dangers that can befall them. Thus, it can be concluded that the lingual forms used by Minangnese in Nagari Padang Laweh have certain functions and meanings, especially to control individual life behaviors and living behaviors in the social environment of the community.

\subsection{The Pattern of Education for Women in Minangkabau through Lingual Forms in the Myth of Palasik}

Thepalasik myth used by the Minangnese in Nagari Padang Laweh has specific purpose, especially for women, either pregnant women or nursing women and their babies. It is intended to giveheritable education pattern to parents in verbal form and for their daughters who are pregnant and breastfeeding. Danandjaja in [15] claims that the function of people truth toward folklore or myth is an educational media for children and adolescent. Thispattern of education is provided to be a regular life pattern to look after themselves and care the babies in uterusor will be born later physically and emationally.

It can be seen in datum 1, datum 5, and datum 6 that use anti-palasik amulets as a recommendation for women in Minangkabau to always look after themselves and their 
children by attaching dasun or garlic to the clothes worn, wearing white bracelets in their hands, and wearing reverse singlet for his son. These objects are only in the form of media, but in the use of lingual, there is a pattern of education provided by parents to their daughters to obey the advice given verbally and from generation to generation.

Meanwhile, in datum 2, datum 3, and datum 4, non-formal education forms are received by women who are pregnant or breastfeeding to keep the womb and babies born well; maintain the propriety of neighboring life, and to always respect and establish friendship with anyone.

Based on many palasik myths that develop in several countries, it seems that therearedifferent point of view in myths about the type of blood sucking creature. There are three kinds of palasik that known by Minangnese[10]. First, palasik for pregnant women, which eat babies who are still in the uterus so babies are born without fontanel even they die. Second, palasik for infants and toddlers. This palasik sucks the blood of babies and children. If anyone is not aware with the existence of palasik or the babies are not immediately treated, the babies will get sick or even it can cause the death. Third, palasik who eat babies who are in the tomb. Besides, another palasik is kuduang which breaks the baby's head in practicing his black magic. Apart from these terms, there are also different Minangbese's perceptiontoward the myths. In Minangkabau, the palasik myth develops to control the behavior of pregnant women and nursing mothers. The control is a social control in the form of education patterns that Minangkabau people expect from women. A woman, especially pregnant women or nursing mothers, must take care of children and themselves outwardly and inwardly.

Meanwhile, in other areas, such as Bali, Thailand and some European countries, the developing myth tends to have function as a spiritual one that is used to scare the people, thus they avoid dangerous conditions. The spiritual experience is owned by people in other regions to prove the existence of another magic world besides the real world that is found. It is certainly different from the views of Minangnese who actually make myths as a social control of women's behavior, especially for pregnant women and nursing mothers.

\section{CONCLUSIONS}

Based on the lingual used by Minangkabau people in spreading out of the palasik myth, it can be concluded that the lingual form has a spiritual function which means social control and psychological functions that alsobecome individual control in life. These functions makeMinangnese have certain pattern of education for women, especially for pregnant women and breastfeeding mothers in order to take care of themselves and their babies physically and emationally.

\section{REFERENCES}

[1] S. Rosa, "Mitos Bundo Kanduang sebagai Tirai Nalar Orang Minangkabau atas Dunianya," Ikadbudi, vol. 5, no. 12, pp. 1-13, 2016.

[2] Y. Asri, "Refleksi Ideologi Wanita Minangkabau Dalam Novel Negeri Perempuan Karya Wisran Hadi," Humaniora, vol. 25, no. 1, pp. 69-81, 2013.

[3] T. Balinisteanu, "Romanian Folklore and Literary Representations of Vampires," Folklore, vol. 127, no. 2, pp. 150-172, May 2016.

[4] G. F. Bendix, Regina, Hasan-Rokem, "a Companion To Folklore," West Sussex: Blackwell Publishing Ltd, 2012, p. 473. 
[5] W. Lestari et al., "Meta-Etnografi Budaya Persalinan Di Indonesia Meta-Ethnography of Delivery Cultures in Indonesia,” J. Masy. Budaya, vol. 20, no. 1, pp. 49-60, 2018.

[6] N. B. Atmadja, L. P. Sendratari, and I. W. Rai, "Deconstructing Gender Stereotypes in Leak," Komunitas Int. J. Indones. Soc. Cult., vol. 7, no. 1, p. 71, 2016.

[7] M. Tiziani, "Vampires and vampirism : pathological roots of a myth," Antrocom, vol. 5, no. May, pp. 133-137, 2014.

[8] B. R. Almond, "Monstrous infants and vampyric mothers in Bram Stoker's Dracula," Int. J. Psychoanal., vol. 88, no. 1, pp. 219-235, Feb. 2007.

[9] M. Harney, "Folklore and Identity in Dracula," Filol. y lingüística, vol. 38, no. 1, pp. 63-81, 2012.

[10] H. Nelwatri, J. Ilmiah, K. Gender, and I. V No, "Helpi Nelwatri / Kafa ' ah Jurnal Ilmiah Kajian Gender Vol. IV No. 1 Tahun 2014," vol. IV, no. 1, pp. 71-79, 2014.

[11] S. Wortham, "Linguistic Anthropology Linguistic Anthropology," in The Handbook of Educational Linguistics, no. January, B. S. and F. Hult, Ed. Oxford: Blackwell Publishing Ltd, 2008, pp. 83-97.

[12] M. D. Steven J. Taylor, Robert Bogdan, Introduction to Qualitative Research Methods: A Guidebook and Resource, 4th ed. New Jersey: John Wiley \& Sions, Inc, 2016.

[13] J. W. Creswell, Research Design: Qualitative, Quantitative and Mixed Approaches (3rd Edition), 3rd ed. California: Sage Publications, 2009.

[14] et. a. B Miles, Matthew, Qualitative Data Analysis : A Methods Sourcebook, 3rd ed. United States of America: Sage Publications, 2014.

[15] H. Andheska, "Kearifan Lokal Masyarakat Minangkabau Dalam Ungkapan Kepercayaan Rakyat," BASINDO J. Kaji. Bahasa, Sastra Indones. dan Pembelajarannya, vol. 2, no. July, pp. 22-28, 2018.

[16] K. Saddhono, "Language and superdiversity: Indonesians knowledging at home and abroad. By Zane Goebel." Soc. Stu. vol. 12 no.1 pp. 113-118, 2018 